tions but also for the very nature of American society." Obviously, he supplemented his fine research skills with an effective crystal ball.

Bill was also a devoted teacher. He regularly taught courses on the presidency, comparative executive behavior, federalism, state politics, policy analysis, politics and aging, and politics and health policy. He taught both undergraduate and graduate students, and he spent a great deal of time outside the classroom guiding his students. He probably supervised more dissertations in the American field than anyone else on the faculty. Bill served for a number of years on the selection committee for state legislative internships. He helped many students, not only at USC, to serve as interns in Sacramento, California.

In latter years, Bill also encouraged junior faculty. He was quick to agree to serve on faculty review committees, and he helped a number of younger faculty to achieve promotion and tenure.

While Bill's research often centered on important government policy and the politically powerful, he was also concerned about the plight of average Americans. He once said in an interview with the media that "All of us should remind ourselves of the importance of ordinary acts of kindliness, like offering to drive an elderly neighbor to a physician or just calling up your 80 year-old grandmother to ask how she's doing. To individually reach out and touch someone among the elderly-by telephone or otherwise-is really as consequential in its own way as any type of collective reform."

In short, Bill was an outstanding scholar and teacher. His research on the presidency, in particular, has shed important light on that critical office. He was an exemplary colleague and the moral backbone of our department. His presence, wisdom, and good humor will be sorely missed.

Bill is survived by his wife, Mary, and daughters Linda and Caroline Lammers.

Sheldon Kamieniecki University of Southern California

\section{Marcella A. MacDonald}

Marcella A. MacDonald, 57, assistant professor of political science at SUNY-Brockport, died at her Brockport home in November 1997. MacDonald had taught at Brockport since 1968, specializing in political theory and women's studies. She was active in faculty governance, including service as chair of her department's governance committee, as a Faculty Senator, as a representative to the faculty union, and as a member of the Women's Studies Board. She was born in Timmins, Ont., and had degrees from the University of Brunswick (B. A.), the University of Melbourne (M.A.), and Yale University (Ph.D.). Dr. MacDonald was a bright, witty, compassionate teacher, colleague, and friend. She scorned the traditional formalities of faculty-student relations and cultivated long-standing friendships with many of her students.

William G. Andrews

SUNY-Brockport

\section{Robert Dale Miewald}

Robert D. Miewald, professor of political science at the University of Nebraska, Lincoln, died October 18, 1997. Bob was born in Chinook, Montana, May 16, 1938. As a boy, he came to know ranching and farming on the Montana plains. After selling the ranch, the family moved to Enterprise, Oregon, where his father was employed by the Forest Service. Bob graduated from Enterprise High School in 1956 and from the University of Oregon in 1960. From 1961 to 1963, he served in the U.S. Army. Following military service, he completed his doctorate in political science at the University of Colorado.

Bob began his professional career at California State University, Long Beach, where he was an assistant professor and coordinator of the graduate program in public administration. In 1971, he joined the faculty of the University of Nebraska, Lincoln as an associate professor. He was promoted to full professor in 1978. At Nebraska, Bob served as chair of the department from 1974 to 1977 and 1988-1990. From 1978, he served as the director of the graduate specialization in policy analysis and program evaluation.

Bob was a master teacher, an engaging and thoughtful writer, an unselfish colleague, dear friend, and mentor. A quite and reserved man in most social settings, in the classroom he was a performer. Whether teaching a class of several hundred or a seminar of less than ten, whether first year or graduate students, Bob made the often dry subject matter of public administration come to life. Courses in personnel administration, budgeting, and management are not the stuff that typically turns students on, but Bob was able to do so. His classes were always full and the students always left with a smile. His style and approach are reflected in his book, Public Administration: A Critical Perspective. He opens with a quote from Ralph Waldo Emerson, "There are some subjects which have kind of a right to dull treatment. Public administration has always been one of those subjects." With criticism and humor, he could turn the dull into the delightful.

Bob also reached students because he had something to say. He would walk them through the world of administration but the journey would not stop with the mechanical and superficial. He dealt with issues at the core. To him, administration and organization were important because they were a way to get things done, but he always cautioned his students to be aware of the dehumanizing potential that lay in the bowels of many an organization. First and foremost, he would remind them, stay committed to your fellow person. Bob would often drive home the point, "being in charge is never an excuse for being a bastard." Many a student left his classroom with a greater understanding of administration. More importantly, many left with a greater understanding of the human condition.

In spite of his success as a teacher, Bob would not allow himself to be nominated for a teaching award. No one knows why; Bob didn't share such things. We suspect that for him, turning students on was simply the job and didn't deserve special recognition. 
In addition to his textbook in public administration, Bob authored two other books: The Bureaucratic State: An Annotated Bibliography, and, with Peter Longo, The Nebraska Constitution: A Reference Guide. He edited and coedited three others. The range and depth of Bob's intellect, his skill in fashioning an argument, his ability to turn a phrase, and his motivation to link public administration to core values are reflected in his essay "On Teaching Public Personnel Administration: A Weberian Perspective."

In it, he calls upon political science to make its courses more relevant to students and asks what could be more relevant than public personnel administration in as much as most, if not, all of our students will wind up as personnel somewhere. Yet, he points out, one is hard pressed to find in introductory texts more than a discussion of technique when it comes to personnel administration. But, he asks, will the drive for improved and better technique and their contribution to rational human control engage students. Not likely. He calls for a fresh perspective moving beyond technique. $\mathrm{He}$ suggests one provided by Weber. Weber's lesson for the teacher of public personnel administration is to remind students that, no matter how imposing a particular technique may be, he/she has the right to ask "What is this all about?" "In the bluntest terms, if one, in the course of his/her organizational life, runs across a practice which appears to be a rotten trick, then it might very well be just that." Ultimately, the issue is one of meaning. Public personnel administration can help students grapple with the problem of meaning, in a context where they are likely to find themselves.

Bob involved himself in community affairs, chairing the Charter Revision Commission for the City of Lincoln and serving as a consultant to the State Constitutional Revision Commission for the State of $\mathrm{Ne}$ braska. Bob also did more than his share of university and department related service. Bob always seemed available for many of the jobs no one else wanted. He served as liaison to the library ensuring that the books and journals faculty wanted were purchased by the library, super- vised student interns, chaired the promotion and tenure committee, and yes, did grade appeals. We knew he did a lot. Just how much, we are still finding out.

Bob, as we used to joke with him, could have been a contender, a dean, provost, perhaps a president of a college or university. But what he wanted was to teach and do it well. He did. He will be missed by his students and colleagues.

Bob is survived by his lovely wife Erika, daughter Christiana, and son Tom.

John Comer

University of Nebraska, Lincoln

Peter Longo

University of Nebraska, Kearney

\section{Edward S. T. Su}

Edward S. T. Su died November 10, 1997, after an extended illness. He was 76 years old. Dr. Su taught political science at Texas A\&I University (now Texas A\&M UniversityKingsville) from 1967 until he retired as a full professor, in 1989.

Su was born in Anhui, China (mainland). He received a law degree from National Anhwei University in China in 1944. He later emigrated from China and became a naturalized United States citizen. He earned a bachelor's degree in political science and criminology from Fresno State College between 1948 and 1950. From 1950-55, he attended the University of Illinois, Champaign-Urbana, where he earned two masters degrees (political science and library science), and began work toward the Ph. D. Su resumed work on the doctorate at Fordham University, in 1958, and was awarded the degree from Fordham, in 1962. His doctorate was in political science with a specialization in international relations.

Dr. Su served from 1944-1947 as an instructor: first, at the Central Police University in Nanking, China, and then at National Anhwei University. In the U.S., he held positions at Pennsylvania State University (cataloger, 1955-57), Rocky Mountain College (assistant professor, political science, 1962-64), Dickinson [North Dakota] State College, 1965-
66, Lake Superior State College (political science professor and library director, 1966-67), and at Texas A\&I, 1967-89.

At Texas A\&I, Su taught United States and Texas government as well as international politics, international law and organizations, politics of China, politics of the Soviet Union, and the politics of Southeast Asia. His publications, mostly in the 1960s, dealt with various aspects of Sino-Soviet Relations. Dr. Su belonged to several professional organizations. Besides the American Political Science Association, he held memberships in the American Academy of Political and Social Science, the International Political Science Association, the International Studies Association, and the Association of Asian Studies. Su was listed in a variety of Who's Who publications in the $1970 \mathrm{~s}$.

Although Dr. Su's personal experience included expropriation of the family business by the Communist government, his perspective on the accomplishments and limitations of the Communist regime was always judicious and well balanced. Su traveled extensively in China once this was allowed. After retirement, he worked on a book on contemporary China, but competing demands and ill health prevented him from finishing it. He had considerable insight concerning how China could blend a healthy degree of modernization and democratization with retention of important elements of traditional Chinese culture and customs.

Dr. Su was a dedicated teacher who encouraged students to take their concerns about international issues beyond the classroom. From 1967 until the mid-1980s, he sponsored a student organization, the International Relations Club. The club, which sometimes had eighty or more members, sponsored informational forums on a variety of international topics, often addressing the immediate concerns of international students at the university. Su was a serious and capable scholar, a model of collegiality and dedication in the political science department, and a valued member of the university community.

Dr. Su's given name, Guang Ping, means "try to help the poor people." 